\title{
Preparation and characterization of alginate and gelatin microcapsules containing Lactobacillus rhamnosus
}

\author{
SUSIANY LOPES ${ }^{1}$, LUCIANO BUENO $^{2}$, FRANCISCO DE AGUIAR JÚNIOR $^{3}$ and CHRISTINE FINKLER ${ }^{3}$ \\ ${ }^{1}$ Departamento de Química, Universidade Federal Rural de Pernambuco, Dom \\ Manoel de Medeiros, s/n, Dois Irmãos, 52171-900 Recife, PE, Brazil \\ ${ }^{2}$ Centro de Engenharia, Modelagem e Ciências Sociais e Aplicadas, Universidade Federal do \\ ABC, Avenida dos Estados, 5001, Bangu, 09210-170 Santo André, SP, Brazil \\ ${ }^{3}$ Universidade Federal de Pernambuco, Centro Acadêmico de Vitória, Alto do Reservatório, \\ s/n, Bela Vista, 55608-680 Vitória de Santo Antão, PE, Brazil
}

Manuscript received on January 31, 2017; accepted for publication on April 3, 2017

\begin{abstract}
This paper describes the preparation and characterization of alginate beads coated with gelatin and containing Lactobacillus rhamnosus. Capsules were obtained by extrusion method using $\mathrm{CaCl}_{2}$ as cross linker. An experimental design was performed using alginate and gelatin concentrations as the variables investigated, while the response variable was the concentration of viable cells. Beads were characterized in terms of size, morphology, scanning electron microscopy (SEM), moisture content, Fourier Transform Infrared Spectrometry (FTIR), thermal behavior and cell viability during storage. The results showed that the highest concentration of viable cells $\left(4.2 \times 10^{9} \mathrm{CFU} / \mathrm{g}\right)$ was obtained for $1 \% \mathrm{w} / \mathrm{v}$ of alginate and $0.1 \% \mathrm{w} / \mathrm{v}$ of gelatin. Capsules were predominantly spherical with a rough surface, a narrow size distribution ranging from 1.53 to $1.90 \mathrm{~mm}$ and a moisture content of $97.70 \pm 0.03 \%$. Furthermore, FTIR and thermogravimetric analysis indicated an interaction between alginate-gelatin. Cell concentration of alginate/gelatin microcapsules was $10^{5} \mathrm{CFU} / \mathrm{g}$ after 4 months of storage at $8^{\circ} \mathrm{C}$.
\end{abstract}

Key words: Probiotics, biopolymers, functional foods, microencapsulation.

\section{INTRODUCTION}

In recent years, consumer demands for foods that contribute directly to people's health have increased considerably. The current trend is that food is not only for nutritional purposes, but also to prevent nutrition-related diseases and improve the physical and mental well-being of consumers (Menrad 2003). In this regard, functional foods play a significant role.

Correspondence to: Christine Lamenha Luna Finkler

E-mail: chrislluna@yahoo.com.br
The term 'functional foods' was first introduced in Japan in the mid-1980s. Over the years, the concept has been modified in Japan, Europe, United States and in national and international organizations. A standard definition for functional food was established to facilitate greater communication between food experts and non-experts, scientists, government officials and the public. According to Martirosyan and Singh (2015) The Functional Food Center (FFC) announced a proposed new definition for 'functional food', and examples of these foods 
include carotenids, dietary (functional and total) fiber, fatty acids, flavonoids, isothiocyanates, minerals, phenolic acids, plant stanols/sterols, polyols, phytoestrogens, soy protein, sulfides/thiols, vitamins, prebiotics and probiotics (Singh 2015).

According to FAO/WHO (2002), probiotics are live microorganisms(bacteria oryeasts), which when ingested or locally applied in sufficient numbers, confer one or more specified demonstrated health benefits for the host. Lactic acid bacteria (LAB) are the most studied bacteria within the probiotic field (Anal and Singh 2007). Among the LAB, Lactobacillus rhamnosus is typically associated with the human gastro-intestinal microbiota, and is one of the most widely studied probiotic bacteria. Lact. rhamnosus is a Gram-positive, non-motile, non-sporulating rod-shaped facultative anaerobic lactic acid bacterium. A number of health benefits have been claimed for Lact. rhamnosus, such as alleviation of inflammation or pathogen-induced barrier dysfunction (Lebeer et al. 2010, Donato et al. 2010), prevention of intestinal injuries induced by rotavirus diarrhea (Liu et al. 2013a), a decrease in the symptoms of atopic dermatitis in children aged 4-48 months (Wu et al. 2015) and prevention of gastrointestinal infectious (Hojsak et al. 2010).

According to the InternationalDairy Federation, the minimum concentration of probiotic should be around $10^{6}-10^{7} \mathrm{CFU} \mathrm{ml}{ }^{-1}$ at the end of product's shelf life (FAO/WHO 2002). In order to exert their health benefits, the minimum recommended therapeutic dose is $10^{8}-10^{9}$ viable cells per day/ dose (Hou et al. 2003). However, the viability of probiotic bacteria in functional foods is dependent on their survival during manufacture and storage and this is affected by several factors. Probiotics must survive in the acidic gastric environment and be able to reach the small intestine and colonize within the host (Corcoran et al. 2005), should be metabolically stable and active in the product (Gilliland 1989), besides factors such as presence of hydrogen peroxide, dissolved oxygen produced by starter cultures, high oxygen content and oxygen permeability through the packaging materials (Shah and Jelen 1990, Shah and Lankaputhra 1997). The oxygen permeability of the packaging material used currently for probiotic is not recommended due the oxygen toxicity in probiotic bacteria.

In order to improve the viability and stability of probiotics, different techniques have been proposed. The development of a microencapsulation matrix can provide a physical barrier during food processing, storage and in the conditions simulating of the gastrointestinal tract (D'Orazio et al. 2015). In this regard, microencapsulation of probiotics into hydrocolloid beads prepared by extrusion (Shaharuddin and Muhamad 2015) and emulsion (Zhao et al. 2017, Zheng et al. 2017) techniques or into spray-dried microparticles (Santos et al. 2014), has been investigated (Doleyres and Lacroix 2005). Alginate is often used as an encapsulating material because it has the benefits of being non-toxic and being readily available (Ding and Shah 2008, Chávarri et al. 2010, Pitigraisorn et al. 2017), besides this, it is a naturally occurring biocompatible and biodegradable linear anionic polysaccharide (Lotfipour et al. 2012).

Different types of Lactobacillus were encapsulated using an alginate hydrogel matrix as encapsulating agent, such as Lactobacillus bulgaricus (Meng-Yan et al. 2014), Lact. plantarum (Wang et al. 2016, Chen et al. 2012), Lact. fermentum (Martin et al. 2013) and Lact. acidophilus (Etchepare et al. 2016). Recent works have studied encapsulation of Lact. rhamnosus using whey protein and isomaltooligosaccharide (Liu et al. 2016), silica (Zhao et al. 2016), pectin (Li et al. 2016), chitosan-alginate (Gandomi et al. 2016), whey protein (Doherty et al. 2012) and alginate (Pirarat et al. 2015).

According to Mokarram et al. (2009), problems related to susceptibility to disintegration in the presence of excess monovalent ions, $\mathrm{Ca}^{2+}$ chelating agents, and harsh chemical environments 
have been related with using alginate. Thus, coating the encapsulated beads with other polymers can improve their chemical and mechanical stability and the effectiveness of the encapsulation system (Krasaekoopt et al. 2006).

The objective of the present work was to optimize the conditions of microencapsulation of the probiotic strain Lact. rhamnosus ATCC 7469 using the extrusion method to obtain alginate/ gelatin capsules and then to evaluate the survival of the encapsulated cells during storage at $8{ }^{\circ} \mathrm{C}$ over a period of 4 months.

\section{MATERIALS AND METHODS}

\section{MATERIALS}

Lact. rhamnosus ATCC 7469 was obtained from the culture collection of the Antibiotics Department of the Federal University of Pernambuco, Brazil. Sodium alginate was purchased from Danisco (Denmark), pectin type LM was purchased from CP Kelco (USA), gelatin, $\mathrm{Na}_{2} \mathrm{HPO}_{4} \cdot 2 \mathrm{H}_{2} \mathrm{O}$ and $\mathrm{KH}_{2} \mathrm{PO}_{4} \cdot 2 \mathrm{H}_{2} \mathrm{O}$ were obtained from Vetec (Brazil), $\mathrm{Na}_{3} \mathrm{C}_{6} \mathrm{H}_{5} \mathrm{O}_{7}, \mathrm{CaCl}_{2}, \mathrm{NaCl}$ and $\mathrm{KCl}$ were purchased from Quimica Moderna (Brazil), MRS broth was purchased from Merck (Germany), glucose was obtained from Nuclear (Brazil) and Agar was purchased from AgarGel (Brazil).

\section{MICROORGANISM}

Lact. rhamnosus was grown in De Man, Rogosa and Sharpe (MRS) broth at $37{ }^{\circ} \mathrm{C}$ using $250 \mathrm{ml}$ Erlenmeyer flasks containing $50 \mathrm{ml}$ of medium. Cultivation was conducted under stationary conditions for $24 \mathrm{~h}$. Culture was harvested by centrifugation (Excelsa II Centrifuge Mod. 206 $\mathrm{BL})$ at $1,000 \mathrm{~g}$ for 10 minutes. The pellet was re-suspended in $30 \mathrm{ml}$ of lyophilization medium (sucrose $10 \% \mathrm{w} / \mathrm{v}$ and gelatin $1 \% \mathrm{w} / \mathrm{v}$ ) and the cell suspension was divided into $3 \mathrm{ml}$ portions in vials. Samples were stored at $-80{ }^{\circ} \mathrm{C}$ for $12 \mathrm{~h}$ and lyophilized for $24 \mathrm{hrs}$ under vacuum $(1,720 \mathrm{mT})$ at $-50{ }^{\circ} \mathrm{C}$. Culture was stored at $8{ }^{\circ} \mathrm{C}$ and bacterial viability was determined using pour plate technique in MRS agar supplemented with $2 \%$ (w/v) glucose in triplicate by cell resuspension in $3 \mathrm{ml}$ saline solution $(\mathrm{NaCl} 0.85 \% \mathrm{w} / \mathrm{v})$.

\section{CULTIVATION CONDITIONS}

Lact. rhamnosus was cultured in MRS broth at 37 ${ }^{\circ} \mathrm{C}$ for $24 \mathrm{hrs}$ using $500 \mathrm{ml}$ schott-flasks containing $100 \mathrm{ml}$ of medium and an inoculum concentration of $5 \%(\mathrm{v} / \mathrm{v})$. For the preparation of inoculum, the content of one vial of lyophilized bacterium $\left(10^{7} \mathrm{CFU} \mathrm{g}{ }^{-1}\right)$ was resuspended in $2 \mathrm{ml}$ of $0.85 \%$ $\mathrm{w} / \mathrm{v}$ saline solution. Samples were withdrawn at various time intervals for analysis of concentration of viable cells with the objective of identifying the exponential phase of growth (data not shown), in order to obtain cells for encapsulation tests.

\section{PREPARATION OF BEADS BY EXTRUSION}

In order to define the conditions for Lact. rhamnosus microencapsulation and maximize the viability of the cells in the microcapsules, two independent variables (alginate concentration and gelatin concentration) were evaluated using a full $2^{2}$ factorial design, with three central points (level $0)$, totaling seven experiments. The tests were performed randomly, and the data was analyzed using Statistica ${ }^{\circledR} 8.0$ software (Statsoft, Tulsa, OK), with a $95 \%$ confidence level. The experimental error was obtained from the mean and standard deviation of the central points. Table I shows the experimental conditions investigated for the experimental design:

Initially, cells were grown as described above for $14 \mathrm{hrs}$ (late exponential phase). The cells were harvested by centrifugation at 3,500 rpm for $10 \mathrm{~min}$, the pellets were washed once with $0.1 \mathrm{M}$ phosphate buffer saline (PBS) and resuspended in $5 \mathrm{ml}$ of PBS so that the cell concentration in the final PBS/cell suspensions was approximately $10^{9} \mathrm{CFU} \mathrm{ml}^{-1}$. 
TABLE I

Codified levels and actual values of the variables studied in the experimental design.

\begin{tabular}{ccc}
\hline Assays & $\begin{array}{c}\text { Sodium Alginate } \\
\text { concentration (\% w/v) }\end{array}$ & $\begin{array}{c}\text { Gelatin concentration } \\
(\% \mathbf{w} / \mathbf{v})\end{array}$ \\
\hline 1 & $1.0(-1)$ & $0.1(-1)$ \\
2 & $5.0(+1)$ & $0.1(-1)$ \\
3 & $1.0(-1)$ & $0.5(+1)$ \\
4 & $5.0(+1)$ & $0.5(+1)$ \\
$5-7$ & $3.0(0)$ & $0.3(0)$ \\
\hline
\end{tabular}

The extrusion technique for the preparation of the beads, as described by Nualkaekul et al. (2013), was modified by altering the volume proportions of cell suspension and alginate. $5 \mathrm{ml}$ of cell suspension was mixed with $5 \mathrm{ml}$ of sodium alginate solution. The concentration of the sodium alginate solution varied according to Table I. Before use, polymer solutions were pasteurized by heating at $72{ }^{\circ} \mathrm{C}$ for 30 secs on a hot plate and then immediately put on ice to cool; it was subsequently used for coating. Pasteurisation was preferred to sterilisation at 121 ${ }^{\circ} \mathrm{C}$, as it is conducted at a lower temperature and reduces the degree of polymer hydrolysis, which takes place during sterilization (Nualkaekul et al. 2013).

The cell/alginate mixture $(1 \mathrm{ml})$ was extruded through a $0.8 \mathrm{~mm}$ diameter needle into sterile $0.15 \mathrm{M}$ $\mathrm{CaCl}_{2}$ (20 ml) using a peristaltic pump (Gilson) at $1.6 \mathrm{ml} \mathrm{min}$. The beads were allowed to harden for $30 \mathrm{~min}$ and were then harvested using a sieve.

Coated beads were prepared by adding the beads produced previously into $30 \mathrm{ml}$ of gelatin solution, according to experimental planning. Gelatin solutions were pasteurised as described above $\left(72{ }^{\circ} \mathrm{C}, 30 \mathrm{~s}\right)$ and immediately put on ice to cool. The suspensions were mixed at $300 \mathrm{rpm}$ for 10 min using an orbital shaker and the coated beads were harvested and washed with PBS. Beads were stored at $8{ }^{\circ} \mathrm{C}$ in penicillin tubes containing sterile water for further characterizations assays.

\section{VIABLE CELL COUNTS}

In order to count viable cells of Lact. rhamnosus in the beads, portions $(0.2 \mathrm{~g})$ of beads were solubilised in a solution of $1.5 \% \mathrm{w} / \mathrm{v}$ sodium citrate and serially diluted in tubes containing sterile saline solution $(\mathrm{NaCl}, 0.85 \% \mathrm{w} / \mathrm{v}) .200 \mu \mathrm{L}$ of the samples were plated on MRS agar supplemented with $2 \%$ $(w / v)$ glucose, using the pour plate technique. The plates were incubated at $37{ }^{\circ} \mathrm{C}$ for $48-72 \mathrm{~h}$ and the results of viable and cultivable cell counts were expressed by $\mathrm{CFU} / \mathrm{g}$.

\section{BEADS CHARACTERIZATION}

Beads obtained using the selected encapsulation conditions were characterized according to the methods described in the following sections.

Size

Direct observation of beads was carried out as follows: Twelve randomly selected beads were placed on dark paper and photographed with a digital photo camera (Canon EOS 70D) with a 100 $\mathrm{mm}$ macro lens. The scale bar was added from a calibrated digital image using the software ImageJ $1.47 \mathrm{v}$.

Size measurements of beads were also evaluated under a microscope (Primostar, Zeiss) and photographed with a digital photo camera (Axiocam ERc5s, Zeiss). This procedure is robust since it works using the calibrated optical microscopy method for evaluation of the prepared microcapsules, as proposed by other authors (Abdelbary et al. 2012).

\section{Micromorphological analysis}

For micromorphological analysis, unused microscope slides were cleaned by soaking in 70 $\%$ alcohol for 10 minutes. Next, alginate beads were stained by $1 \mathrm{ml}$ of $1 \%$ aqueous toluidine blue (Sigma-Aldrich, St. Louis, MO) and rinsed 
with distilled water for 30 minutes and 5 minutes, respectively. The stained capsules were placed on the glass slides, covered with a coverslip and photographed using a digital camera (Axiocam ERc5s, Zeiss) coupled to an optical microscope (Primostar, Zeiss), under oil immersion with x1000 magnification.

\section{Scanning electron microscopy}

The topographical properties of beads were investigated by scanning electron microscopy (SEM) (EVO LS15) at an accelerating voltage potential of $20 \mathrm{KV}$. Prior to examination, beads were prepared on aluminum stubs and coated with gold under an atmosphere of argon.

\section{The moisture content}

The moisture content of the beads $(X p)$ was determined according to the methodology described in agreement with the Association of Official Analytical Chemists (AOAC 2016). A 5 g portion of the beads was heated for $3 \mathrm{~h}$ at $105{ }^{\circ} \mathrm{C}$. After cooling in a desiccator, the beads were weighed and the procedure was repeated until a constant weight ( $c w)$ was obtained. The moisture content $(\mathrm{Xp} \%)$ was calculated using Equation 1. The tests were performed in triplicate.

$$
X p(\%)=\left[\frac{5-c w}{5}\right] x 100
$$

\section{FTIR and thermogravimetric analysis}

Fourier Transform Infrared (FTIR) spectra were recorded with a spectrometer (Varian model 640IR) using $\mathrm{KBr}$ discs and collecting data from 400 $4000 \mathrm{~cm}^{-1}$.

Thermal analysis was performed by differential thermal analysis (DTA) and Thermogravimetry Analysis (TGA) using a thermoanalyzer (Shimadzu 60WS, Tokyo, Japan). All measurements employed a linear heating rate of $10{ }^{\circ} \mathrm{C} \mathrm{min}^{-1}$, nitrogen as carrier gas and a platinum empty pan as reference material. Portions of sample $(10 \mathrm{mg})$ were heated linearly from $30{ }^{\circ} \mathrm{C}$ to $800{ }^{\circ} \mathrm{C}$. The analyses were carried out in the Laboratory of Physics and Chemistry of Polymeric Materials at the Federal Rural University of Pernambuco.

Viability of encapsulated Lact. rhamnosus during storage

Beads of Lact. rhamnosus were stored in penicillin tubes containing sterile distilled water that were hermetically sealed and stored at $8{ }^{\circ} \mathrm{C}$. Probiotic survival was evaluated by performing viable cell counts immediately after the beads' preparation and after 30,60, 90 and 120 days of storage.

\section{RESULTS}

\section{THE EFFECT OF DIFFERENT BEAD} FORMULATIONS ON THE VIABILITY OF Lact. rhamnosus

Figure 1 ( $a$ and $b$ ) shows the response surface and the contour curve, respectively, for the concentration of viable cells for experimental design as a function of the alginate and gelatin concentrations. The highest concentration of viable cells $\left(4.2 \times 10^{9}\right.$ CFU g ${ }^{-1}$ ) was obtained for $1 \% \mathrm{w} / \mathrm{v}$ of alginate and $0.1 \% \mathrm{w} / \mathrm{v}$ of gelatin. The Pareto graph (Figure 1c) revealed that the alginate showed a statistically significant negative effect (- 4.59), indicating that higher viable cell counts were obtained at lower alginate concentrations. The variables of gelatin concentration and the factor of interaction between alginate/gelatin were not statistically significant, suggesting that the coating of the capsules with gelatin did not exert a positive effect on the cell viability of beads. 


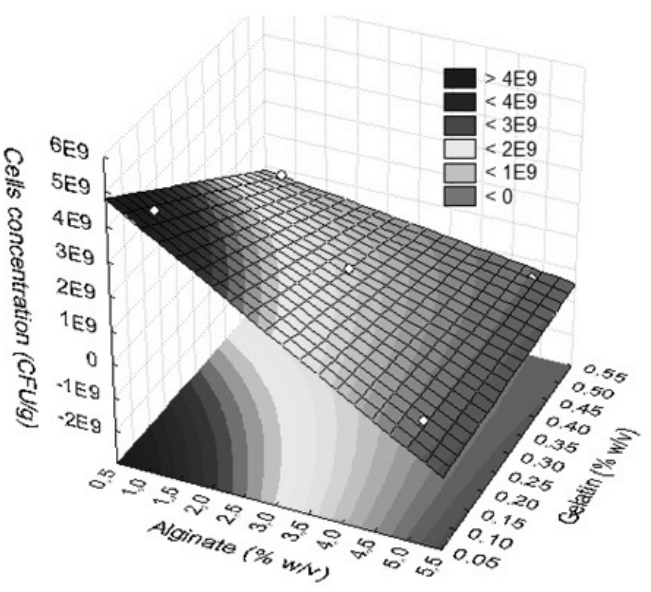

(a)

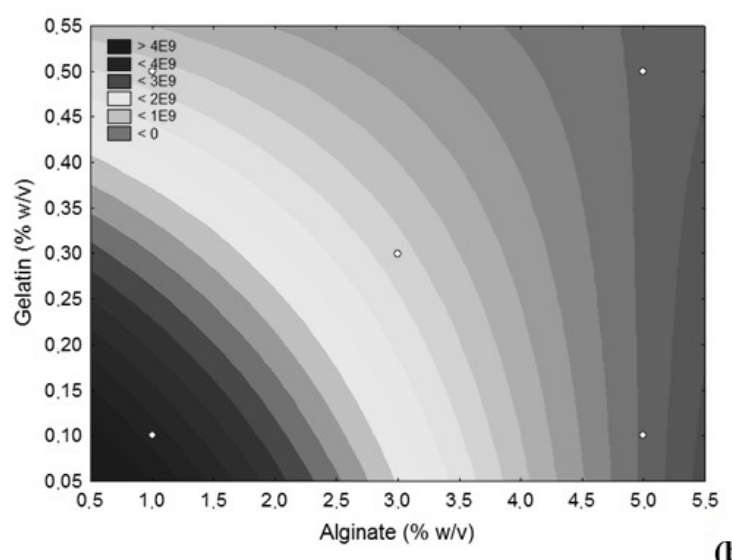

(b)

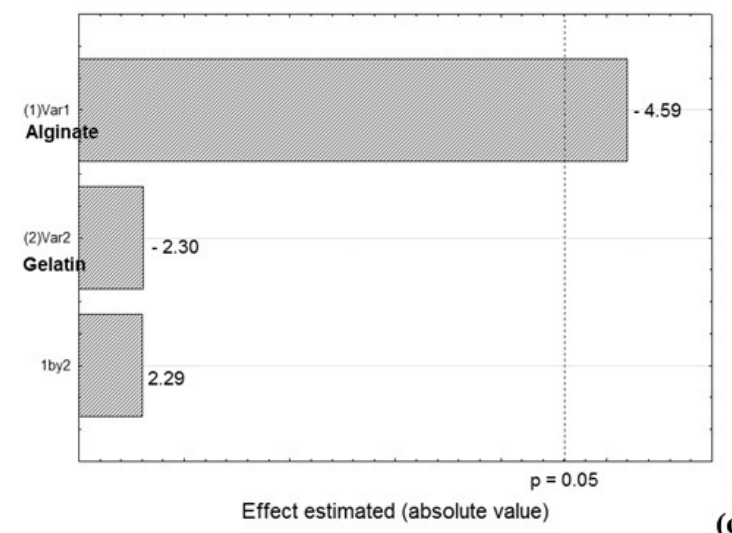

(c)

Figure 1 - Response surface (a), contour curvature (b) and Pareto diagram (c) of viable cell concentration of Lact. rhamnosus as a function of the alginate and gelatin concentrations.
CHARACTERIZATION OF PREPARED BEADS: SIZE, MICROMORPHOLOGICAL ANALYSIS AND SCANNING ELECTRON MICROSCOPY

The alginate/gelatin beads for the selected formulation $(1 \% \mathrm{w} / \mathrm{v}$ of alginate and $0.1 \% \mathrm{w} / \mathrm{v}$ of gelatin) were regular and spherical in shape and a white, opaque color (Figures $2 \mathrm{a}$ and $2 \mathrm{~b}$ ) and ranged in size from 1.53 to $1.90 \mathrm{~mm}$. A cross section of bead (x1000 magnification) shows the integrity of Lact. rhamnosus cells entrapped within the capsule (Figure 2c). The presence of cells confirms that this technique is effective for microencapsulating this Lactobacillus.

Scanning electron microscopy images for capsules prepared using $1 \% \mathrm{w} / \mathrm{v}$ of alginate and $0.1 \% \mathrm{w} / \mathrm{v}$ of gelatin show that most of the capsules were predominantly spherical, although some were found to be elongated or irregular (Figure 3a) and exhibited a rough surface, not homogeneous and were constituted of polyhedral particles (Figure $3 b)$. These characteristics are compatible with shrinkage occurring during the drying process (Sriamornsak et al. 2007).

\section{THE MOISTURE CONTENT}

The moisture content can be defined as the percentage weight of water in relation to the dry weight and is an important factor in evaluating the viability of microorganisms. The alginate/ gelatin microcapsules containing Lact. rhamnosus presented a moisture content of $97.70 \pm 0.03 \%$. Similar results were found by Belščak-Cvitanović et al. (2015), being characteristic of microparticles produced from polysaccharides that form gels and have the capacity to retain water.

FOURIER TRANSFORM INFRARED

SPECTROMETRY (FTIR) AND THERMAL ANALYSIS

Figure 4 shows the IR spectra of sodium alginate (4a) and humid (4b) and dehydrated (4c) alginate/ gelatin microcapsules. Thermal stability of 


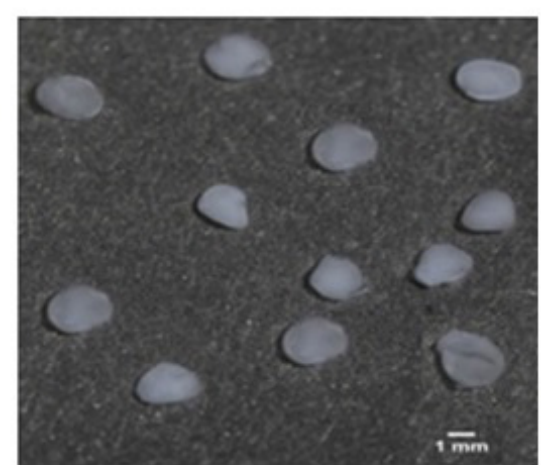

(a)

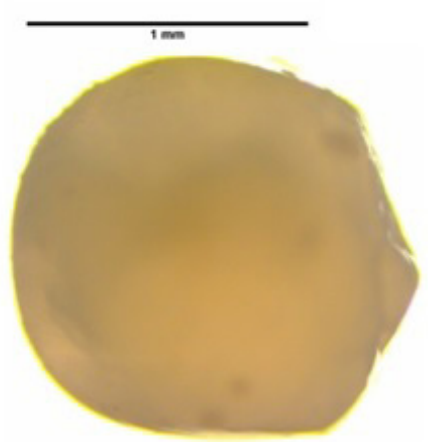

(b)

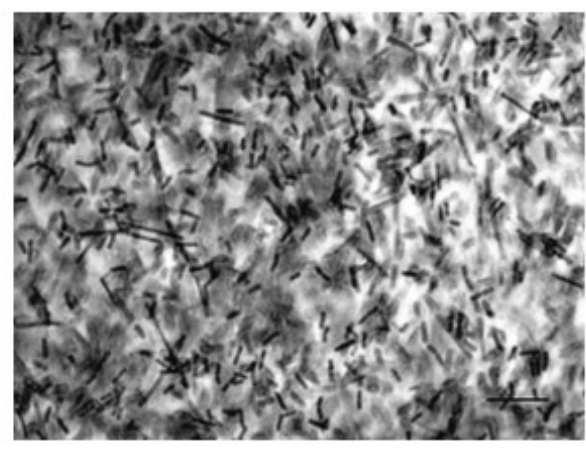

(c)

Figure 2 - Photographic images of alginate/gelatin beads (1\% w/v of alginate and $0.1 \% \mathrm{w} / \mathrm{v}$ of gelatin). (a) Direct observation; (b) Microscopy image (x40 magnification); (c) Cross section of bead (x1000 magnification).

alginate/gelatin microcapsules was determined from Thermogravimetry Analysis (TGA) and Differential Thermal Analysis (DTA), as shown in Figure 5.

\section{EVALUATION OF THE VIABILITY OF ENCAPSULATED BACTERIA DURING STORAGE}

In this study, we tested the cell viability of alginate/ gelatin microcapsules containing Lact. rhamnosus for the long-term storage stability at $8{ }^{\circ} \mathrm{C}$ for 120 days (Figure 6). We found that within four months of storage, viability was reduced from $10^{9}$ to $10^{5}$ $\mathrm{CFU} \mathrm{g}{ }^{-1}$, which indicated around $5 \log$ reductions in the bacterial population.

\section{DISCUSSION}

The results indicated that the concentration of viable cells decreases with an increase in the concentrations of the polymers. According to Chandramouli et al. (2004), alginate concentrations less than $1 \%(\mathrm{w} / \mathrm{v})$ are quite difficult to encapsulate because of the decreased viscosity of the alginate solution and concomitantly less ion sites for the cross-linking. Also, concentrations more than $2 \%$ $(\mathrm{w} / \mathrm{v})$ are too viscous and cause difficulties in the process of encapsulation. Moreover, the majority of previous reports in literature suggest that sodium alginate has generally been used at a concentration varying from $0.75 \%$ to $2 \%(\mathrm{w} / \mathrm{v})$.
The beads characteristics are similar to those observed by Lotfipour et al. (2012), who observed results for diameters of alginate beads containing Lact. acidophilus ranging from 1.59 to $1.67 \mathrm{~mm}$.

According to Totosaus et al. (2013), alginate microparticles usually had a core due to the heterogeneous gelation mechanism. This effect was reported by Skjak-Brak et al. (1989), who described that during the mechanism of gelification, the polymer concentration is much higher on the surface than in the centre of the gels, which results in uneven surfaces.

Sodium alginate (curve 4a) presented a band centered at $3430 \mathrm{~cm}^{-1}$ that corresponds to the functional group $\mathrm{O}-\mathrm{H}$. The band at $2929 \mathrm{~cm}^{-1}$ is attributed to the symmetrical and asymmetrical stretching of C-H. The peak observed at $2150 \mathrm{~cm}^{-1}$ is attributed to the group $\mathrm{CO}_{2}$ group. The increase in the peak intensity at $1611 \mathrm{~cm}^{-1}$ corresponds the symmetrical stretching of $\mathrm{COO}^{-}$. Peaks observed at $1416 \mathrm{~cm}^{-1}$ and $1304 \mathrm{~cm}^{-1}$ are attributed to the asymmetrical stretching of the $\mathrm{COO}^{-}$and $\mathrm{C}-\mathrm{O}$ group. Peaks at $1093 \mathrm{~cm}^{-1}$ and $1031 \mathrm{~cm}^{-1}$ are associated with the stretching with regards to the C-O group. Besides, peaks at $946 \mathrm{~cm}^{-1}, 890 \mathrm{~cm}^{-1}$ and $818 \mathrm{~cm}^{-1}$ are attributed to the $\mathrm{C}-\mathrm{H}$ vibration of the pyranose (ring of the alginate) group (Falkeborg et al. 2015, Bekhit et al. 2016). 

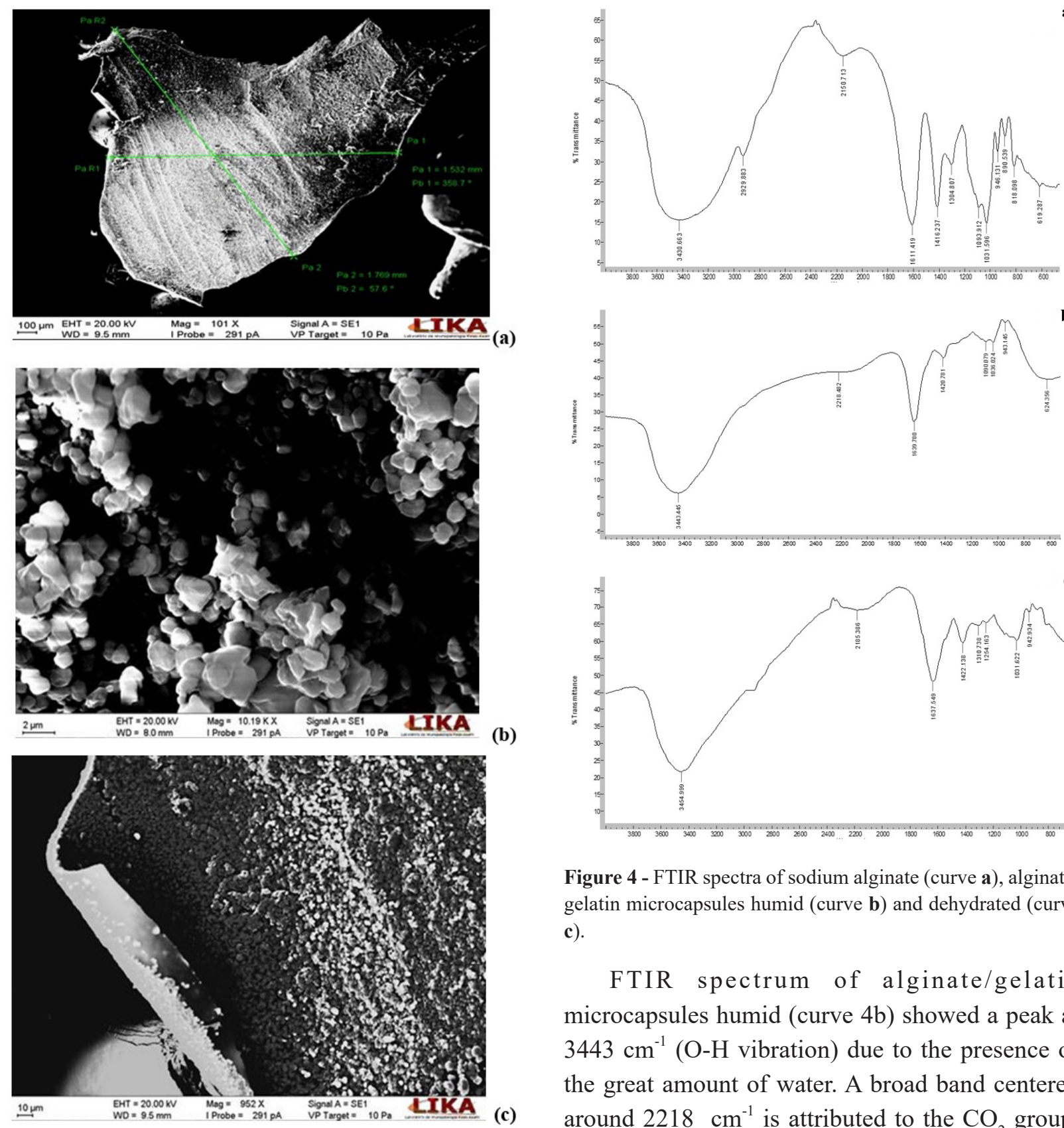

(b)
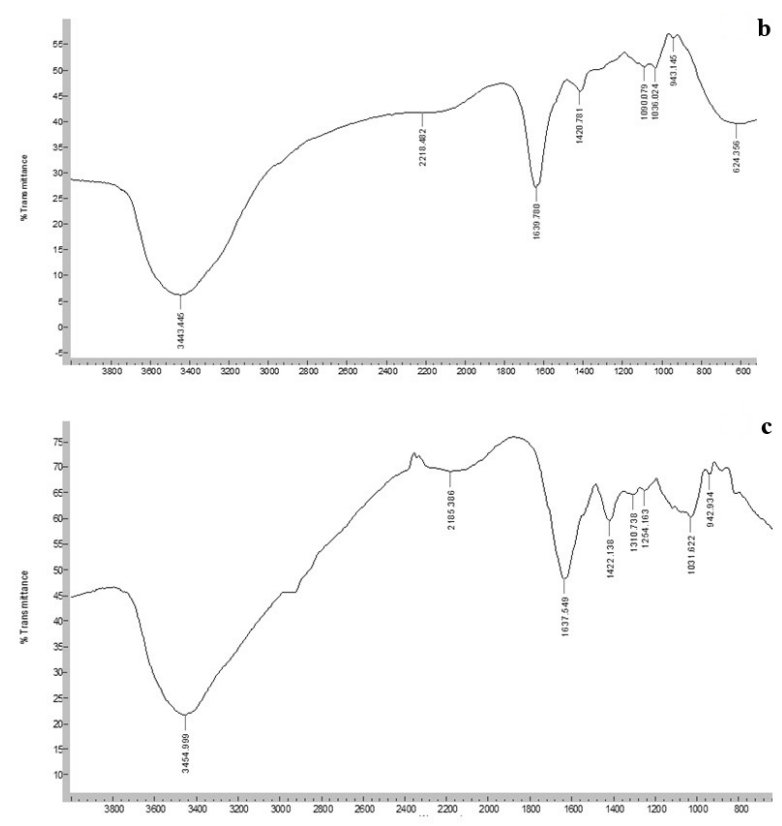

Figure 4 - FTIR spectra of sodium alginate (curve a), alginate/ gelatin microcapsules humid (curve b) and dehydrated (curve c).

FTIR spectrum of alginate/gelatin microcapsules humid (curve $4 \mathrm{~b}$ ) showed a peak at $3443 \mathrm{~cm}^{-1}$ (O-H vibration) due to the presence of the great amount of water. A broad band centered around $2218 \mathrm{~cm}^{-1}$ is attributed to the $\mathrm{CO}_{2}$ group. The increase in peak intensity at $1639 \mathrm{~cm}^{-1}$ is characteristic of the $-\mathrm{CONH}_{2}$ group and indicates that the negative group of the alginate could be associated with the positive load of the gelatin. The gelatin, an amphoteric polymer that presents $\mathrm{pH}$ below his point isoelectric, could form a complex with anionic polysaccharides, such as the alginate, through electrostatic interactions (Saravanan and Rao 2010), leading to the formation 

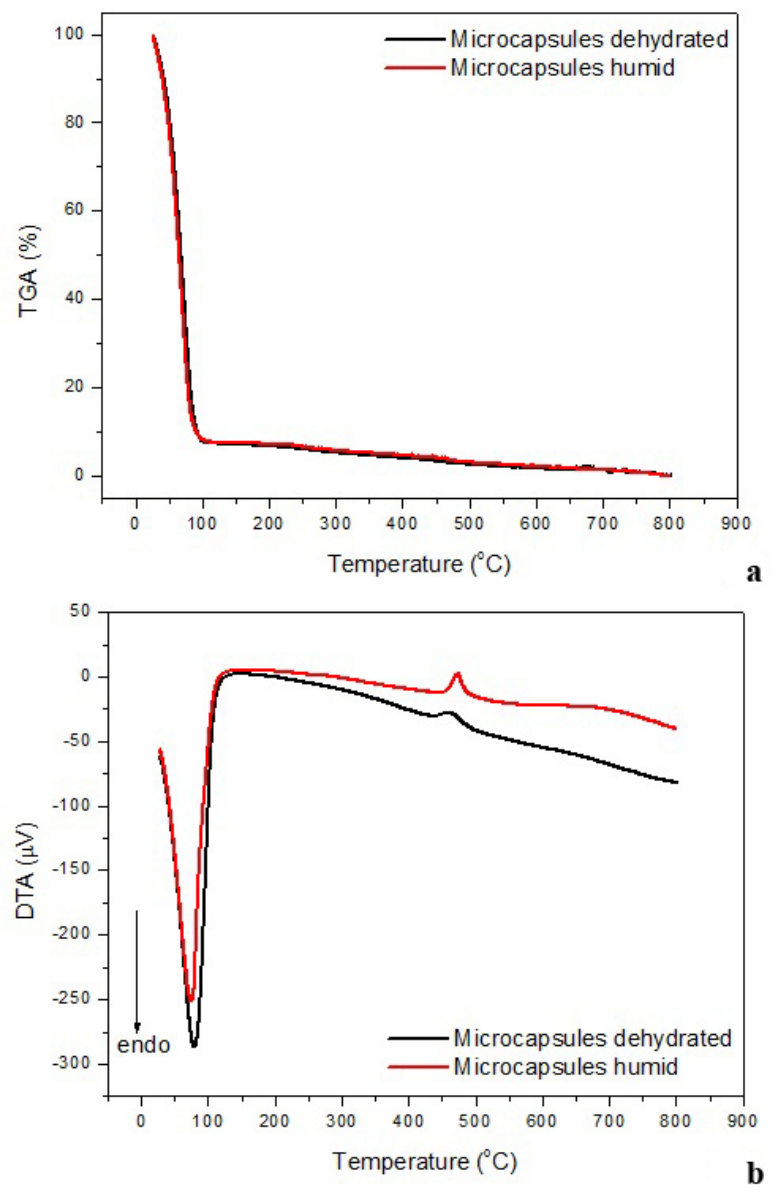

Figure 5 - TGA (a) and DTA (b) curves obtained for alginate/ gelatin microcapsules humid and dehydrated.

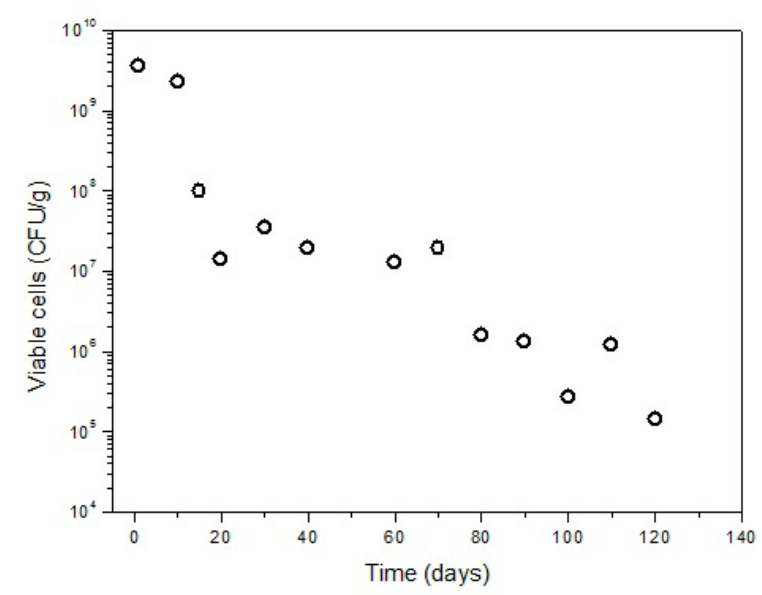

Figure 6 - Concentration of viable cells of Lact. rhamnosus in alginate capsules covered with gelatin for 120 days of storage at $8{ }^{\circ} \mathrm{C}$. of a polyelectrolyte complex, as described by Nualkaekul et al. (2013).

The peak at $1420 \mathrm{~cm}^{-1}$ is attributed to the asymmetrical stretching of COO-. Peaks at 1090 $\mathrm{cm}^{-1}$ and $1036 \mathrm{~cm}^{-1}$ are associated to the $\mathrm{C}-\mathrm{H}$ group of guluronic units, and the peak at $943 \mathrm{~cm}^{-1}$ corresponds to the $\mathrm{C}-\mathrm{H}$ group of the ring pyranose (El-Ghaffara et al. 2012, Xiao et al. 2014).

Alginate/gelatin microcapsules dehydrated (curve 4c) showed a peak at $3454 \mathrm{~cm}^{-1}$ regarding the functional group O-H linked to the hydrogen. The peak observed at $2185 \mathrm{~cm}^{-1}$ is attributed to the $\mathrm{CO}_{2}$ group. The increase in the peak intensity at $1637 \mathrm{~cm}^{-1}$ corresponding to $\mathrm{CONH}_{2}(\mathrm{C}=\mathrm{O})$ indicates that the negative group of the alginate could be associated with the positive load of the gelatin. The peak at $1422 \mathrm{~cm}^{1}$ is due to the asymmetrical stretching of the COO- linked to the hydrogen of the alginate. Signals around $1310 \mathrm{~cm}^{-1}$, $1254 \mathrm{~cm}^{-1} / 1031 \mathrm{~cm}^{-1}$ and $942 \mathrm{~cm}^{-1}$ were attributed to vibrations of the $\mathrm{C}-\mathrm{N}$ group of the gelatin, $\mathrm{C}-\mathrm{O}$ and $\mathrm{C}-\mathrm{H}$ groups, respectively. With the drying of the capsules, the molecules of water were affected and the bands decreased (Devi and Kakat 2013).

Comparing the FTIR spectrum profile of pure alginate with the microcapsules spectrum it can be observed that the FTIR spectrum of pure alginate showed a peak at $2929 \mathrm{~cm}^{-1}$ characteristic of C-H stretching, while FTIR spectrum of microcapsules presented group C-H associated to peaks $1090 \mathrm{~cm}^{-1}$ and $1036 \mathrm{~cm}^{-1}$ corresponding to guluronic units for microcapsules humid and a peak at $942 \mathrm{~cm}^{-1}$ for microcapsules dehydrated. In addition, the peaks at $1639 \mathrm{~cm}^{-1 /} 1637 \mathrm{~cm}^{-1}$ for microcapsules humid and dehydrated, respectively, are characteristic of the $\mathrm{CONH}_{2}$ group and indicate the interaction between alginate and gelatin.

TGA curves (5a) are typical of weight loss, and the major mass loss refers to a thermal event characteristically endothermic (between $30{ }^{\circ} \mathrm{C}$ and $80{ }^{\circ} \mathrm{C}$ - curve $5 \mathrm{~b}$ ). As this event begins at room temperature, it is assumed that this mass loss is 
related to moisture. The mass loss of the dehydrated capsules is due to residual moisture, and the overlapping curves suggest that even with different initial contents of moisture this phenomenon occurs in the same way for both samples. The end of the thermal event occurs at a temperature above $100{ }^{\circ} \mathrm{C}$, and this event may be associated with a bound water molecule. Therefore, by analyzing the results, sodium alginate has two types of water in its structure, a portion of unbound water related to moisture and another portion of water bound to the polymer.

The results indicate that up to $100{ }^{\circ} \mathrm{C}$ the samples contained a low relative tenor of the organic matter, and starting from this temperature the samples degraded quickly during the heating up to $800^{\circ} \mathrm{C}$.

Alginate/gelatin microcapsules showed an exothermic decomposition peak at $450{ }^{\circ} \mathrm{C}$, a temperature higher than that observed by Sarmento et al. (2006) and Anbinder et al. (2011), who observed exothermic peaks for sodium alginate at 240 and $247{ }^{\circ} \mathrm{C}$, respectively. This is probably due the presence of gelatin in the composition of microcapsules in this work, demonstrating that the presence of gelatin improve the chemical stability of the microcapsules. The oxidative degradation of the polymers can supply important information about behavior of polymeric materials under different atmospheric conditions (Liu et al. 2013b).

According to Stojanovic et al. (2012), the thermal decomposition of polymers includes the steps of dehydration and depolymerization accompanied by the rupture of $\mathrm{C}-\mathrm{O}$ and $\mathrm{C}-\mathrm{C}$ bonds and formation of $\mathrm{CO}, \mathrm{CO}_{2}$ and $\mathrm{H}_{2} \mathrm{O}$. Decomposition could be due to the combustion or even crystallization of the amorphous material (Gooch 2011).

Since that during the processing and/or storage of probiotics, cellular damageand loss of cellviability could occur, an appropriate microencapsulation assures that the microorganisms survive processing and remain viable throughout storage (Thomas et al. 2014). In this work, beads maintained the cell survival of Lact. rhamnosus, reaching $10^{5} \mathrm{CFU} \mathrm{g}^{-1}$ after 4 months. On the contrary, when Trabelsi et al. (2014) studied the efficiency of immobilizing Lactobacillus plantarum TN9 strain in alginate using gelatin as a coating material, verified that the viability of encapsulated Lact. plantarum could be preserved more than $5.8 \log \mathrm{CFU} \mathrm{ml^{-1 }}$ after 35 days of incubation at $4{ }^{\circ} \mathrm{C}$, and no effect was observed when gelatin was used. Chávarri et al. (2010) microencapsulated Lactobacillus gasseri in alginate-chitosan capsules and they observed that after 28 days of storage, the cellular viability decreased from $10^{9}$ to $10^{7} \mathrm{CFU} \mathrm{ml}{ }^{-1}$.

In conclusion, alginate/gelatin beads encapsulating probiotic Lact. rhamnosus at concentrations of $1 \% \mathrm{w} / \mathrm{v}$ of alginate and 0.1 $\% \mathrm{w} / \mathrm{v}$ of gelatin resulted in formation of beads containing $10^{9} \mathrm{CFU} \mathrm{g}^{-1}$. The microparticles were spherical with slightly roughened surfaces, and interaction between polymers was confirmed by FTIR and thermal analysis. Beads maintained the cell survival of Lact. rhamnosus, reaching $10^{5}$ CFU $\mathrm{g}^{-1}$ after 4 months. Thus, this formulation could be considered promising in the production of microcapsules containing probiotics because even after 4 months of storage a mass of $10 \mathrm{~g}$ of microcapsules would be enough to reach the minimum quantity recommended by FAO.

\section{ACKNOWLEDGMENTS}

The authors are grateful to Coordenação de Aperfeiçoamento de Pessoal de Nível Superior (CAPES), for the financial support.

\section{REFERENCES}

ABDELBARY A, EL-GENDY NA AND HOSNY A. 2012. Microencapsulation approach for orally extended delivery of glipizide: In vitro and in vivo evaluation. Indian J Pharm Sci 74: 319-330. 
ANAL AK AND SINGH H. 2007. Recent advances in microencapsulation of probiotics for industrial applications and targeted delivery. Trends Food Sci Tech 18: 240-251.

ANBINDER PS, DELADINO L, NAVARRO AS, AMALVY JI AND MARTINO MN. 2011. Yerba mate extract encapsulation with alginate and chitosan systems: Interactions between active compound encapsulation polymers. J Encap Adsorp Sci 1: 80-87.

AOAC - ASSOCIATION OF OFFICIAL ANALYTICAL CHEMISTS. 2016. Official methods of analysis. 20th edition. Arlington, USA, 2214 p.

BEKHIT M, SÁNCHEZ-GONZÁLEZ L, MESSAOUD GB AND DESOBRY S. 2016. Design of microcapsules containing Lactococcus lactis subsp. lactis in alginate shell and xanthan gum with nutrients core. LWT - Food Sci Technol 68: 446-453.

BELŠČAK-CVITANOVIĆ A, KOMES D, KARLOVIĆ S, DJAKOVIĆ S, ŠPOLJARIĆ I, MRŠIĆ G AND JEŽEK D. 2015. Improving the controlled delivery formulations of caffeine in alginate hydrogel beads combined with pectin, carrageenan, chitosan and psyllium. Food Chem 167: 378386.

CHANDRAMOULI V, KAILASAPATHY K, PEIRIS P AND JONES M. 2004. An improved method of microencapsulation and its evaluation to protect Lactobacillus spp. in simulated gastric conditions. J Microbiol Meth 56: 27-35.

CHÁVARRI M, MARAÑÓN I, ARES R, IBÁÑEZ FC, MARZO F AND VILLARÁN MC. 2010. Microencapsulation of a probiotic and prebiotic in alginatechitosan capsules improves survival in simulated gastrointestinal conditions. Int J Food Microbiol 142: 185-189.

CHEN S, ZHAO Q, FERGUSON LR, SHU Q, WEIR I AND GARG S. 2012. Development of a novel probiotic delivery system based on microencapsulation with protectants. Appl Microbiol Biotechnol 93: 1447-1457.

CORCORAN BM, STANTON C, FITZGERALD GF AND ROSS RP. 2005. Survival of probiotic Lactobacilli in acidic environments is enhanced in the presence of metabolizable sugars. Appl Environ Microbiol 71: 3060-3067.

DEVI N AND KAKAT DK. 2013. Smart porous microparticles based on gelatin/sodium alginate polyelectrolyte complex. J Food Eng 117: 193-204.

DING WK AND SHAH NP. 2008. Survival of free and microencapsulated probiotic bacteria in orange and apple juices. Int Food Res J 15: 219-232.

DOHERTY SB, AUTY MA, STANTON C, ROSS RP, FITZGERALD GF AND BRODKORB A. 2012. Survival of entrapped Lactobacillus rhamnosus GG in whey protein micro-beads during simulated ex vivo gastro-intestinal. Int Dairy J 22: 31-43.
DOLEYRES Y AND LACROIX C. 2005. Technologies with free and immobilised cells for probiotic bifidobacteria production and protection. Int Dairy J 15: 973-988.

DONATO KA, GAREAU MG, WANG YJ AND SHERMAN PM. 2010. Lactobacillus rhamnosus GG attenuates interferon-\{gamma $\}$ and tumour necrosis factor-alphainduced barrier dysfunction and proinflammatory signalling. Microbiology 156: 3288-3297.

D'ORAZIO G, GENNARO PD, BOCCARUSSO M, PRESTI I, BIZZARO G, GIARDINA S, MICHELOTTI A, LABRA M AND LA FERLA B. 2015. Microencapsulation of new probiotic formulations for gastrointestinal delivery: in vitro study to assess viability and biological properties. Appl Microbiol Biotechnol 99: 9779-9789.

EL-GHAFFARA MAA, HASHEMA MS, EL-AWADYB MK AND RABIEC AM. 2012. pH-sensitive sodium alginate hydrogels for riboflavin controlled release. Carbohyd Polym 89: 667-675.

ETCHEPARE MA, RADDATZ GC, CICHOSKI AJ, FLORES EMM, BARIN JS, ZEPKA LQ, JACOB-LOPES E, GROSSO CRF AND MENEZES CR. 2016. Effect of resistant starch (Hi-maize) on the survival of Lactobacillus acidophilus microencapsulated with sodium alginate. J Funct Food 21: 321-329.

FALKEBORG M, PAITAID P, SHU AN, PÉREZ B AND GUO Z. 2015. Dodecenyl succinylated alginate as a novel material for encapsulation and hyperactivation of lipases. Carbohyd Polym 133: 194-202.

FAO/WHO. 2002. Guidelines for the evaluation of probiotics in food. Food and Agriculture Organization of United Nations and World Health Organization. World Health Organization, London, $11 \mathrm{p}$.

GANDOMI H, ABBASZADEH S, MISAGHI A, BOKAIE S AND NOORI N. 2016. Effect of chitosan-alginate encapsulation with inulin on survival of Lactobacillus rhamnosus GG during apple juice storage and under simulated gastrointestinal conditions. LWT - Food Sci Technol 69: 365-371.

GILLILAND SE. 1989. Acidophilus milk-products - a review of potential benefits to consumers. J Dairy Sci 72: 2483 2495.

GOOCH JW. 2011. Encyclopedic dictionary of polymers. Springer-Verlag, USA, $520 \mathrm{p}$.

HOJSAK I, SNOVAK N, ABDOVIĆ S, SZAJEWSKA H, MISAK Z AND KOLACEK S. 2010. Lactobacillus GG in the prevention of gastrointestinal and respiratory tract infections in children who attend day care centers: a randomized, double-blind, placebo-controlled trial. Clin Nutr 29: 312-316.

HOU RCW, LIN MY, WANG MMC AND TZEN JTC. 2003. Increase of viability of entrapped cells of Lactobacillus delbrueckii ssp. bulgaricus in artificial sesame oil emulsions. J Dairy Sci 86: 424-428. 
KRASAEKOOPT W, BHANDARI B AND DEETH HC. 2006. Survival of probiotics encapsulated in chitosan-coated alginate beads in yoghurt from UHT- and conventionally treated milk during storage. LWT - Food Sci Technol 39: 177-183.

LEBEER S, VANDERLEYDEN J AND DE KEERSMAECKER SC. 2010. Adaptation factors of the probiotic Lactobacillus rhamnosus GG. Benef Microbes 1: 335-342.

LI R, ZHANG Y, POLK DB, TOMASULA PM, YAN F AND LIU L. 2016. Preserving viability of Lactobacillus rhamnosus GG in vitro and in vivo by a new encapsulation system. J Control Release 230: 79-87.

LIU F ET AL. 2013a. Lactobacillus rhamnosus GG on rotavirus-induced injury of ileal epithelium in gnotobiotic pigs. J Pediatr Gastroenterol Nutr 57: 750-758.

LIU L, LI X, ZHU Y, BORA AFM, ZHAO Y, DU L, LI D AND BI W. 2016. Effect of microencapsulation with Maillard reaction products of whey proteins and isomaltooligosaccharide on the survival of Lactobacillus rhamnosus. LWT - Food Sci Technol 73: 37-43.

LIU X, WANG Y, YU L, TONG Z, CHEN L, LIU H AND LI X. 2013b. Thermal degradation and stability of starch under different processing conditions. Starch 65: 48-60.

LOTFIPOUR F, MIRZAEEI S AND MAGHSOODI M. 2012. Preparation and characterization of alginate and psyllium beads containing Lactobacillus acidophilus. Sci World J, 8 p.

MARTIN MJ, LARA-VILLOSLADA F, RUIZ MA AND MORALES ME. 2013. Effect of unmodified starch on viability of alginate-encapsulated Lactobacillus fermentum CECT5716. LWT - Food Sci Technol 53: 480-486.

MARTIROSYAN DM AND SINGH J. 2015. A new definition of functional food by FFC: what makes a new definition unique? Funct Foods Health Dis 5: 209-223.

MENG-YAN C, WEI Z, QIU-YUE D, ZHEN-HUA L, LU-E S AND ZHEN-XING T. 2014. Activity of encapsulated Lactobacillus bulgaricus in alginate-whey protein microspheres. Braz Arch Biol Technol 57: 736-741.

MENRAD K. 2003. Market and marketing of functional food in Europe. J Food Eng 56: 181-188.

MOKARRAM RR, MORTAZAVI SA, NAJAFI MBH AND SHAHIDI F. 2009. The influence of multi stage alginate coating on survivability of potential probiotic bacteria in simulated gastric and intestinal juice. Food Res Int 42: 1040-1045.

NUALKAEKUL S, COOK MT, KHUTORYANSKIY VV AND CHARALAMPOPOULOS D. 2013. Influence of encapsulation and coating materials on the survival of Lactobacillus plantarum and Bifidobacterium longum in fruit juices. Food Res Int 53: 304-311.

PIRARAT N, PINPIMAI K, RODKHUM C, CHANSUE N, OOI EL, KATAGIRI T AND MAITA M. 2015. Viability and morphological evaluation of alginate-encapsulated
Lactobacillus rhamnosus GG under simulated tilapia gastrointestinal conditions and its effect on growth performance, intestinal morphology and protection against Streptococcus agalactiae. Anim Feed Sci Tech 207: 93-103.

PITIGRAISORN P， SRICHAISUPAKIT K, WONGPADUNGKIAT N AND WONGSASULAK S. 2017. Encapsulation of Lactobacillus acidophilus in moist-heat-resistant multilayered microcapsules. J Food Eng 192: 11-18.

SANTOS RC, FINKLER L AND FINKLER CLL. 2014. Microencapsulation of Lactobacillus casei by spray drying. J Microencap 1: 1-9.

SARAVANAN M AND RAO KP. 2010. Pectin-gelatin and alginate-gelatin complex coacervation for controlled drug delivery: Influence of anionic polysaccharides and drugs being encapsulated on physicochemical properties of microcapsules. Carbohyd Polym 80: 808-816.

SARMENTO B, FERREIRA D, VEIGA F AND RIBEIRO AN. 2006. Characterization of insulin loaded alginate nanoparticles produced by ionotropic pre-gelation through DSC and FTIR studies. Carbohyd Polym 66: 1-7.

SHAH NP AND JELEN P. 1990. Survival of lactic acid bacteria and their lactases under acidic conditions. J Food Sci 55: 506-509.

SHAH NP AND LANKAPUTHRA WEV. 1997. Improving viability of Lactobacillus acidophilus and Bifidobacterium spp. in yogurt. Int Dairy J 7: 349-356.

SHAHARUDDIN S AND MUHAMAD II. 2015. Microencapsulation of alginate-immobilized bagasse with Lactobacillus rhamnosus NRRL 442: Enhancement of survivability and themotolerance. Carbohyd Polym 119: 173-181.

SINGH U. 2015. Benefits from foods beyond basic nutrition. Indian J Pharm Sci Res 5: 212-219.

SKJAK-BRAK G, GRASDALE KH, DRAGET KI AND SMIDSROD O. 1989. Inhomogeneous polysaccharide ionic gels. Carbohyd Polym 10: 31-54.

SRIAMORNSAK P, SUNGTHONGJEEN S AND PUTTIPIPATKHACHORN S. 2007. Use of pectin as a carrier for in tragastric floating drug delivery: carbonate salt contained beads. Carbohyd Polym 67: 436-445.

STOJANOVIC R, BELSCAK-CVITANOVIC A, MANOJLOVIC V, KOMES D, NEDOVIC V AND BUGARSKI B. 2012. Encapsulation of thyme (Thymus serpyllum L.) aqueous extract in calcium alginate beads. J Sci Food Agr 92: 685-696.

THOMAS MB, VAIDYANATHAN M, RADHAKRISHNAN K AND RAICHUR AM. 2014. Enhanced viability of probiotic Saccharomyces boulardii encapsulated by layerby-layer approach in $\mathrm{pH}$ responsive chitosan-dextran sulfate polyelectrolytes. J Food Eng 136: 1-8.

TOTOSAUS A, ARIZA-ORTEGA TJ AND PÉREZCHABELA ML. 2013. Lactic acid bacteria 
microencapsulation in sodium alginate and other gelling hydrocolloids mixtures. J Food Nutr Res 52: 107-120.

TRABELSI I, AYADI D, BEJAR W, BEJAR S, CHOUAYEKH H AND SALAH RB. 2014. Effects of Lactobacillus plantarum immobilization in alginate coated with chitosan and gelatin on antibacterial activity. Int J Biol Macromol 64: 84-89.

WANG L, YU X, XU H, AGUILAR ZP AND WEI H. 2016. Effect of skim milk coated inulin-alginate encapsulation beads on viability and gene expression of Lactobacillus plantarum during freeze-drying. LWT - Food Sci Technol 68: 8-13.

WU YJ, WU WF, HUNG CW, KU MS, LIAO PF, SUN HL, LU KH, SHEU JN AND LUE KH. 2015. Evaluation of efficacy and safety of Lactobacillus rhamnosus in children aged 4-48 months with atopic dermatitis: An 8-week, double-blind, randomized, placebo-controlled study. J Microbiol Immunol Infect 1: 1-9.
XIAO Q, GU X AND TAN S. 2014. Drying process of sodium alginate films studied by two-dimensional correlation ATR-FTIR spectroscopy. Food Chem 164: 179-184.

ZHAO M, QU F, WU Z, NISHINARI K, PHILLIPS GO AND FANG Y. 2017. Protection mechanism of alginate microcapsules with different mechanical strength for Lactobacillus plantarum ST-III, Food Hydrocolloids 66: 396-402.

ZHAO Z, XIE X, WANG Z, TAO Y, NIU X, HUANG X, LIU L AND LI Z. 2016. Immobilization of Lactobacillus rhamnosus in mesoporous silica-based material: An efficiency continuous cell-recycle fermentation system for lactic acid production. J Biosci Bioeng 121: 645-651.

ZHENG H, GAO M, REN Y, LOU R, XIE H, YU W, LIU $X$ AND MA X. 2017. An improved pH-responsive carrier based on EDTA-Ca-alginate for oral delivery of Lactobacillus rhamnosus ATCC 53103. Carbohyd Polym 155: 329-335. 